(c) American Dairy Science Association, 2003.

\title{
Fractionized Milk Composition During Removal of Colostrum and Mature Milk
}

\author{
C. E. Ontsouka, ${ }^{*}$ R. M. Bruckmaier, $†$ and J. W. Blum* \\ *Institute of Animal Genetics, Nutrition and Housing, University of Berne, \\ Bremgartenstr. 109a, CH-3012 Berne, Switzerland \\ †Institute of Physiology, Technical University Munich, \\ Weihenstephaner Berg 3, D-85350 Freising, Germany
}

\begin{abstract}
Experiments were designed to study compositional differences in colostrum and mature milk and during the course of milk removal. Fractionized milk samples during the course of machine milking were analyzed in single (right rear) quarters in the cisternal fraction, after $25,50,75$, and $100 \%$ of spontaneously removed milk, in residual milk, and in composite samples from all quarters on d 2 (colostrum) and in wk 4 (mature milk) of lactation. Somatic cell counts; concentrations of dry matter, total protein, insulin-like growth factor$\mathrm{I}$, insulin, prolactin, tumor necrosis factor- $\alpha, \mathrm{Na}$, and $\mathrm{Cl} ; \gamma$-glutamyltransferase activity; and electrical conductivity were higher, whereas lactose concentration was lower on $d 2$ than in wk 4. Concentrations of fat, potassium chloride, and osmolarity did not differ between lactational periods. During the course of milking, concentrations of dry matter, fat, lactose, and potassium, and osmolarity increased, whereas somatic cell counts, protein, insulin like-growth factor-I, insulin, prolactin, and sodium concentrations, electrical conductivity and $\gamma$-glutamyltransferase activity decreased on d 2, and protein, sodium, and electrical conductivity decreased in wk 4 . In conclusion, various milk constituents differed considerably between lactational periods (colostrum and mature milk). Milk isotonicity was only in part associated with lactose concentration. Electrical conductivity was associated with $\mathrm{Na}, \mathrm{K}$, and fat concentrations and was highest in the cisternal fraction. Changes in milk constituents during milking need to be considered if milk samples are taken for analytical purposes and to evaluate the health status of the udder. (Key words: Dairy cow, milk composition, colostrum, mature milk)
\end{abstract}

Abbreviation key: $\gamma \mathbf{G T}=\gamma$-glutamyltransferase; $\mathbf{P R L}=$ prolactin; TNF- $\alpha=$ tumor-necrosis factor $-\alpha$.

Received March 6, 2002.

Accepted October 21, 2002.

Corresponding author: J. W. Blum; e-mail: juerg.blum@itz. unibe.ch.

\section{INTRODUCTION}

Colostrum and milk contain fat, proteins, lactose, and minerals, which are of nutritional importance. In addition, they contain vitamins, immunoglobulins, hormones, growth factors, cytokines, enzymes, and other bioactive peptides (Koldovsky, 1980; Campana and Baumrucker, 1995; Swaisgood, 1995; Blum and Hammon, 2000), metabolites derived from alveolar epithelial cells (Peaker and Linzell, 1975), and immunocompetent cells (Lee et al., 1980). Breed, age, nutrition, and health status of the cow are well known to influence milk composition. Colostrum differs greatly in composition from mature milk and meets the nutritional requirements of the newborn (Blum and Hammon, 2000; Blum and Baumrucker, 2002).

Colostrum and milk components are secreted by different mechanisms (Patton and Jensen, 1975). Secretion is regulated by both local and systemic factors. Local factors include intramammary pressure (Bruckmaier and Blum, 1998) and an autocrine feedback inhibitor of lactation (Wilde and Peaker, 1990). Milk is secreted between milkings and accumulates in alveolar and cisternal compartments (Bruckmaier et al., 1994a; Davis et al., 1998; Knight et al., 1994).

During milking the cisternal fraction is first removed. Removal of the alveolar fraction requires milk ejection by oxytocin, which commences in dairy cows at about 1 min after tactile udder stimulation has started, resulting in transfer of milk to the cistern for removal (Bruckmaier and Blum, 1996). Milk ejection is a continuous process throughout milking (Bruckmaier et al., 1994b). Milk ejection is delayed if only small amounts of milk are stored in the udder, i.e., towards the end of lactation and if intervals between milkings are short (Bruckmaier et al., 1994b; Bruckmaier and Hilger, 2001). Because milk ejection is a continuous process throughout milking, it can be hypothesized that there are also continuous changes in milk composition during the course of milking.

The objective of this study was to measure the concentration of nutritional and nonnutritional milk components in colostrum (on $\mathrm{d} 2$ of lactation) and in mature 
milk (at wk 4 of lactation) in fractionized milk samples. Analyses were performed in one quarter only, because the duration of milk flow of individual quarters is variable (Wellnitz et al., 1999), i.e., an exact analysis of compositional changes of milk constituents on a whole udder basis is not possible. Such data are of importance if milk constituents are analyzed to monitor animal health and to determine which components may be ingested by suckling calves.

\section{MATERIALS AND METHODS}

\section{Animals and Husbandry}

Sixteen Red Holstein $\times$ Simmental cows were used. All animals belonged to the dairy herd of the Swiss Federal Research Station of Animal Production, Posieux, Switzerland and were in their second to fourth lactation.

Cows were fed a standard diet (consisting of grass silage, hay, and concentrates) used at the research station for lactating dairy cows and according to recommendations (Jans and Kessler, 1999).

Cows were tested weekly for SCC and milk composition. All animals were free of clinical udder health problems, i.e., SCC of mature milk were below 100,000 cells/ $\mathrm{ml}$ in all quarters at the end of the previous lactation and after wk 1 in the current lactation until the end of the experiment. A prophylactic antibiotic treatment was routinely performed at drying off. Cows were milked twice daily at 0600 and 1600 and were kept in a tie-stall barn.

\section{Experimental Procedures}

Experimental milkings were carried out during routine milking time using a quarter milking claw (Surge RX, Westfalia Separator GmbH, Oelde, Germany). Milking was performed at a vacuum level of $45 \mathrm{kPa}$ and a pulsation rate of $60 \mathrm{cycles} / \mathrm{min}$ at a ratio of 70:30. Milk samples were collected from the right rear quarter during one evening milking.

In eight cows, milking was performed and quarter milk samples were taken during the colostrum period on d 2 of lactation (third milking). In another eight cows, samples were taken during one afternoon milking in wk 4 of lactation. To obtain a sample of the cisternal fraction before milk ejection, milking was performed without prestimulation (Bruckmaier and Blum, 1996). The cisternal sample was the first $100 \mathrm{ml}$ of milk obtained after the start of milking. During further milking, $100-\mathrm{ml}$ milk samples were collected for every 0.5 $\mathrm{kg}$ of sequentially removed milk from the right rear quarter until milk flow ceased. Based on the actual quarter milk yield, the obtained fractions were selected and mixed to obtain milk fractions corresponding to $25,50,75$, and $100 \%$ of removed milk. An additional fraction was collected during removal of residual milk after i.v. injection of 10 i.u. oxytocin. An additional sample was collected from the total milk obtained from all quarters.

\section{Laboratory Procedures}

For DM determination, $1 \mathrm{~g}$ of whole milk or colostrum was placed for $3 \mathrm{~h}$ at $105^{\circ} \mathrm{C}$ for water evaporation followed by measuring the remaining weight.

Concentrations of fat, protein, and lactose were determined by infrared spectroscopy (Milko-Scan 605; Foss Electric, 3400 Hillerød, Denmark). The SCC were determined by the fluoro-opto-electronic method (Fossomatic; Foss Electric, 3400 Hillerød, Denmark).

For the determination of $\gamma$-glutamyltransferase $(\gamma$ GT) activity, milk samples were defatted by centrifugation at $4^{\circ} \mathrm{C}$ (for $15 \mathrm{~min}$ at $3000 \times \mathrm{g}$ ) after casein coagulation by addition of chymosin. The $\gamma$-GT activity was measured with a kit (\# 0751510) from F. Hoffmann-La Roche (Basle, Switzerland) using an automatic analyzer (Cobas Mira Plus, F. Hoffmann-La Roche).

Concentrations of IgG were measured in milk serum after immunodiffusion in agarose by precipitation with a rabbit anti-bovine IgG serum as described (Vacher and Blum, 1993). To obtain milk whey, samples were defatted by centrifugation at $4^{\circ} \mathrm{C}$ (for $15 \mathrm{~min}$ at $3000 \times$ g). For IgG measurement, the colostrum was diluted 1:10.

Concentrations of insulin and prolactin (PRL) were determined in whey of colostrum and mature milk. To obtain milk whey, samples were defatted by centrifugation at $4^{\circ} \mathrm{C}$ (for $15 \mathrm{~min}$ at $3000 \times \mathrm{g}$ ). Then, the infranatant was centrifuged again (for $30 \mathrm{~min}$ at $20,000 \times \mathrm{g}$ ). The infranatant was used for hormone determinations by radioimmunoassay as described by Hadorn et al. (1997). Concentrations of IGF-I were determined in samples of whole milk and in colostrum by radioimmunoassay as described by Hadorn et al. (1997). Immunoreactive tumor necrosis factor- $\alpha$ (TNF- $\alpha$ ) in whey of milk and colostrum $(3 \times$ centrifugation) was measured by specific double antibody radioimmunoassay as described by Blum et al. (2000).

The elements $\mathrm{Na}, \mathrm{K}$, and $\mathrm{Cl}$ were measured in milk whey by means of ion selective electrodes (Cobas Mira Plus, F. Hoffmann-La Roche).

The osmolarity was determined in whole milk using indirect measurement of osmotic pressure by the MultiOsmette Model 2430 Automatic Osmometer (Precision Sampling Inc., San Rafael, California, USA). The sample osmolarity was computed by measurement of freezing point depression, which was proportional to the 
Table 1. Contents of composite milk from all quarters on d 2 and in wk 4 of lactation.

\begin{tabular}{llcc}
\hline & & Day 2 (colostrum) & Week 4 (mature milk) \\
\hline Parity & & $2.8 \pm 0.9$ & $2.9 \pm 0.8$ \\
Daily milk yield & $\mathrm{kg}$ & $16.8 \pm 1.7^{*}$ & $33.9 \pm 0.9$ \\
Dry matter & $\mathrm{g} / \mathrm{kg}$ & $70.5 \pm 16^{*}$ & $117 \pm 12$ \\
Fat & $\mathrm{g} / \mathrm{L}$ & $52.0 \pm 3.2^{*}$ & $57.6 \pm 6.7$ \\
Protein total & $\mathrm{g} / \mathrm{L}$ & $43.9 \pm 0.9^{*}$ & $32.5 \pm 1.0$ \\
Lactose & $\mathrm{g} / \mathrm{L}$ & $27 \pm 1^{*}$ & $49.9 \pm 0.5$ \\
Na & $\mathrm{mmol} / \mathrm{L}$ & $44 \pm 1$ & $20 \pm 1$ \\
$\mathrm{~K}$ & $\mathrm{mmol} / \mathrm{L}$ & $38 \pm 2^{*}$ & $41 \pm 1$ \\
$\mathrm{Cl}$ & $\mathrm{mmol} / \mathrm{L}$ & $5.6 \pm 0.2^{*}$ & $29 \pm 1$ \\
Elec. conductivity & $\mathrm{mS} / \mathrm{cm}$ & $295 \pm 2$ & $4.9 \pm 0.2$ \\
Osmolarity & $\mathrm{mOsm} / \mathrm{L}$ & $1479 \pm 585^{*}$ & $274 \pm 9$ \\
Somatic cells & $\times 10^{6} / \mathrm{L}$ & $103 \pm 21^{*}$ & $41 \pm 15$ \\
IGF-I & $\mu \mathrm{g} / \mathrm{L}$ & $4.55 \pm 1.04^{*}$ & $4 \pm 1$ \\
Insulin & $\mu \mathrm{g} / \mathrm{L}$ & $120 \pm 16^{*}$ & $0.37 \pm 0.02$ \\
Prolactin & $\mu \mathrm{g} / \mathrm{L}$ & $5.0 \pm 0.6^{*}$ & $15.4 \pm 1.0$ \\
TNF- $\alpha$ & $\mu \mathrm{g} / \mathrm{L}$ & $137 \pm 9^{*}$ & $1.8 \pm 0.2$ \\
$\gamma$-GT & $\mu \mathrm{kat} / \mathrm{L}$ & $28.3 \pm 5.7^{*}$ & $24 \pm 8$ \\
IgG & $\mathrm{g} / \mathrm{L}$ & $1.5 \pm 0.1$ \\
\hline
\end{tabular}

* Means are significantly different $(P<0.05)$ between $\mathrm{d} 2$ and wk 4 .

concentration of the solute (Blagden's law). Sample results were then computed by linear interpolation using the average standard readings.

Electrical conductivity was measured at $25^{\circ} \mathrm{C}$ using the LDM electrode from WTW (Wissenschaftlich-Technische Werkstätten GmbH, Weilheim, Germany).

\section{Statistical Analyses}

Values of milk traits are expressed as means \pm SEM. Differences between stages of lactation and changes during the course of milking at each stage of lactation were tested for significance $(P<0.05)$ by analysis of variance using the MIXED models procedure of SAS. Because SCC could not be assumed to be normally distributed the SCC values were converted to log value for statistical calculations. The MIXED models included period of lactation, the animal, and the milk fraction (if applicable) as class variables. For all calculations on composite milk samples, the animal was the repeated subject during the course of milking. Differences were localized by Bonferroni's t-test. In addition, Pearson's correlation coefficients among various parameters were calculated.

\section{RESULTS}

\section{Characteristics of Colostrum and Mature Milk in Milk from all Quarters}

Major constituents. Dry matter, protein concentration (Table 1), and SCC were higher $(P<0.05)$ on d 2 (colostrum), and lactose concentration was lower $(P<$ 0.05 ) compared with wk 4 (mature milk). Concentration of fat was numerically but not significantly higher on d 2 than in wk 4 . On d 2, protein was correlated with IGF-I $(\mathrm{r}=0.76, P<0.05)$, insulin $(\mathrm{r}=0.71, P<0.05)$, $\gamma$-GT $(\mathrm{r}=0.75, P<0.05)$, IgG $(\mathrm{r}=0.88, P<0.05)$, and nonsignificantly with PRL $(\mathrm{r}=0.68, P=0.06)$.

Milk electrolytes, osmolarity and electrical conductivity. Concentrations of $\mathrm{Na}$ and $\mathrm{Cl}$ (Table 1) were significantly $(P<0.05)$ higher in colostrum than in mature milk. Osmolarity was numerically, but not significantly higher on $\mathrm{d} 2$ than in wk 4 . Electrical conductivity (Table 1$)$ was higher $(P<0.05)$ on $d 2$ than in wk 4 . On $\mathrm{d} 2, \mathrm{Na}$ was highly correlated with $\mathrm{Cl}(\mathrm{r}=0.9, P<$ 0.05 ), electrical conductivity was closely and negatively correlated with lactose $(\mathrm{r}=-0.92, P<0.05)$, and osmolarity was closely correlated with $\gamma$-GT $(\mathrm{r}=0.94, P<$ $0.05)$ and nonsignificantly with total protein $(r=0.80$, $P=0.06)$.

Hormones, enzymes, and immunoglobulin $G$. The concentrations of IGF-I, insulin, PRL, TNF- $\alpha$, and IgG and $\gamma$-GT activity were higher $(P<0.05)$ in colostrum (d 2) than in mature milk (Table 1). The IgG concentration was closely correlated with $\mathrm{Na}$ and $\mathrm{Cl}$ on $\mathrm{d} 2(\mathrm{r}=0.92, P<0.05)$.

\section{Milk Characteristics During the Course of Milking}

Major constituents. As shown in Table 2, concentrations of DM and fat increased $(P<0.05)$ from cisternal to $100 \%$ alveolar and residual fractions during milking on $\mathrm{d} 2$ and in wk 4 . The concentration of lactose (Table 2 ) was lowest in the cisternal fraction and increased $(P<$ $0.05)$ in alveolar fractions. The concentration of protein (Table 2$)$ on $d 2$ decreased $(P<0.05)$ transiently from the cisternal to the $25 \%$ alveolar fraction and decreased further towards the end of milking. In wk 4, protein 
Table 2. Fractionized milk composition and osmolarity and electrical conductivity on d 2 and wk 4 of lactation.

\begin{tabular}{|c|c|c|c|c|c|c|c|c|}
\hline \multirow[b]{2}{*}{ Traits } & & \multirow{2}{*}{$\begin{array}{l}\text { Stages of } \\
\text { lactation }\end{array}$} & \multicolumn{6}{|c|}{ Milk fractions } \\
\hline & & & Cisternal & $25 \%$ & $50 \%$ & $75 \%$ & $100 \%$ & Residual \\
\hline Dry matter & $\mathrm{g} / \mathrm{L}$ & $\begin{array}{l}\text { Day } 2 \\
\text { Week } 4\end{array}$ & $\begin{array}{l}126 \pm 14^{\mathrm{C}} \\
110 \pm 10^{\mathrm{C}}\end{array}$ & $\begin{array}{l}131 \pm 8^{\mathrm{C}} \\
121 \pm 8^{\mathrm{C}}\end{array}$ & $\begin{array}{l}144 \pm 12^{\mathrm{C}} \\
126 \pm 4^{\mathrm{C}}\end{array}$ & $\begin{array}{l}171 \pm 19^{\mathrm{B}} \\
136 \pm 2^{\mathrm{C}}\end{array}$ & $\begin{array}{l}210 \pm 23^{\mathrm{A}} \\
166 \pm 8^{\mathrm{B}}\end{array}$ & $\begin{array}{l}218 \pm 22^{\mathrm{A}} \\
217 \pm 11^{\mathrm{A}}\end{array}$ \\
\hline Fat & $\mathrm{g} / \mathrm{L}$ & $\begin{array}{l}\text { Day } 2 \\
\text { Week } 4\end{array}$ & $\begin{array}{l}25.9 \pm 7.9^{\mathrm{E}} \\
22.4 \pm 4.1^{\mathrm{E}}\end{array}$ & $\begin{array}{l}44.5 \pm 10.8^{\mathrm{D}} \\
33.6 \pm 4.9^{\mathrm{DE}}\end{array}$ & $\begin{array}{l}69.9 \pm 7.7^{\mathrm{C}} \\
45.3 \pm 4.1^{\mathrm{CD}}\end{array}$ & $\begin{array}{l}93.2 \pm 11.6^{\mathrm{B}} \\
55.3 \pm 3.8^{\mathrm{C}}\end{array}$ & $\begin{aligned} 124.5 & \pm 12.9^{\mathrm{A}} \\
84.3 & \pm 4.6^{\mathrm{B}}\end{aligned}$ & $\begin{array}{l}129.2 \pm 17.5^{\mathrm{A}} \\
130.7 \pm 9.4^{\mathrm{A}}\end{array}$ \\
\hline Protein & $\mathrm{g} / \mathrm{L}$ & $\begin{array}{l}\text { Day } 2 \\
\text { Week } 4\end{array}$ & $\begin{array}{l}53.0 \pm 3.6^{\mathrm{A}} \\
33.3 \pm 1.3^{\mathrm{AB}}\end{array}$ & $\begin{array}{l}49.3 \pm 2.0^{\mathrm{B}} \\
34.1 \pm 1.0^{\mathrm{A}}\end{array}$ & $\begin{array}{l}51.6 \pm 3.2^{\mathrm{A}} \\
33.5 \pm 1.0^{\mathrm{AB}}\end{array}$ & $\begin{array}{l}51.8 \pm 3.1^{\mathrm{A}} \\
33.1 \pm 1.0^{\mathrm{AB}}\end{array}$ & $\begin{array}{l}49.6 \pm 2.9^{\mathrm{B}} \\
31.8 \pm 0.9^{\mathrm{B}}\end{array}$ & $\begin{array}{l}46.1 \pm 1.8^{\mathrm{B}} \\
29.9 \pm 0.7^{\mathrm{C}}\end{array}$ \\
\hline SCC & $\log / \mathrm{L}$ & $\begin{array}{l}\text { Day } 2 \\
\text { Week } 4\end{array}$ & $\begin{array}{l}8.77 \pm 8.58^{\mathrm{BC}} \\
7.77 \pm 7.49\end{array}$ & $\begin{array}{l}8.44 \pm 7.99^{\mathrm{C}} \\
7.14 \pm 6.0\end{array}$ & $\begin{array}{l}8.81 \pm 8.47^{\mathrm{ABC}} \\
7.14 \pm 6.6\end{array}$ & $\begin{array}{l}8.94 \pm 8.68^{\mathrm{AB}} \\
7.28 \pm 6.70\end{array}$ & $\begin{array}{l}8.99 \pm 8.69^{\mathrm{AB}} \\
7.68 \pm 7.08\end{array}$ & $\begin{array}{l}9.06 \pm 8.74^{\mathrm{A}} \\
7.81 \pm 6.48\end{array}$ \\
\hline $\mathrm{Na}$ & $\mathrm{mol} / \mathrm{L}$ & $\begin{array}{l}\text { Day } 2 \\
\text { Week } 4\end{array}$ & $\begin{array}{l}31 \pm 3^{\mathrm{A}} \\
23 \pm 2^{\mathrm{B}}\end{array}$ & $\begin{array}{l}26 \pm 2^{\mathrm{C}} \\
17 \pm 1^{\mathrm{C}}\end{array}$ & $\begin{array}{l}27 \pm 2^{\mathrm{BC}} \\
19 \pm 2^{\mathrm{C}}\end{array}$ & $\begin{array}{l}30 \pm 3^{\mathrm{AB}} \\
19 \pm 1^{\mathrm{C}}\end{array}$ & $\begin{array}{l}32 \pm 4^{\mathrm{A}} \\
25 \pm 2^{\mathrm{A}}\end{array}$ & $\begin{array}{l}31 \pm 3^{\mathrm{A}} \\
24 \pm 1^{\mathrm{A}}\end{array}$ \\
\hline $\mathrm{K}$ & $\mathrm{mmol} / \mathrm{L}$ & $\begin{array}{l}\text { Day } 2 \\
\text { Week } 4\end{array}$ & $\begin{array}{l}38 \pm 3^{\mathrm{D}} \\
33 \pm 3^{\mathrm{D}}\end{array}$ & $\begin{array}{l}45 \pm 2^{\mathrm{A}} \\
36 \pm 3^{\mathrm{CD}}\end{array}$ & $\begin{array}{l}45 \pm 1^{\mathrm{A}} \\
34 \pm 3^{\mathrm{CD}}\end{array}$ & $\begin{array}{l}44 \pm 2^{\mathrm{A}} \\
38 \pm 3^{\mathrm{BC}}\end{array}$ & $\begin{array}{l}44 \pm 2^{\mathrm{A}} \\
38 \pm 2^{\mathrm{B}}\end{array}$ & $\begin{array}{l}45 \pm 2^{\mathrm{A}} \\
44 \pm 2^{\mathrm{A}}\end{array}$ \\
\hline Conductivity & $\mathrm{mS} / \mathrm{cm}$ & $\begin{array}{l}\text { Day } 2 \\
\text { Week } 4\end{array}$ & $\begin{array}{l}6.05 \pm 0.14^{\mathrm{A}} \\
5.63 \pm 0.26^{\mathrm{A}}\end{array}$ & $\begin{array}{l}5.70 \pm 0.17^{\mathrm{A}} \\
5.25 \pm 0.23^{\mathrm{A}}\end{array}$ & $\begin{array}{l}5.93 \pm 0.22^{\mathrm{A}} \\
4.86 \pm 0.16^{\mathrm{B}}\end{array}$ & $\begin{array}{l}5.61 \pm 0.15^{\mathrm{AB}} \\
4.87 \pm 0.11^{\mathrm{B}}\end{array}$ & $\begin{array}{l}5.43 \pm 0.21^{\mathrm{BC}} \\
4.75 \pm 0.13^{\mathrm{B}}\end{array}$ & $\begin{array}{l}5.25 \pm 0.20^{\mathrm{C}} \\
4.36 \pm 0.11^{\mathrm{C}}\end{array}$ \\
\hline
\end{tabular}

${ }^{\mathrm{A}, \mathrm{B}}$ Means of milk fractions with different letters are different $(P<0.05)$.

concentration decreased $(P<0.05)$ from the $25 \%$ to the $100 \%$ alveolar fraction and decreased further in residual fractions. SCC decreased numerically but not significantly from high values in the cisternal fraction to lowest values in the first alveolar fraction and increased further during the course of milking $(P<0.05)$ with highest values in the residual fraction; these changes were not significant in wk 4 .

Milk electrolytes, osmolarity, and electrical conductivity. Concentrations of $\mathrm{Na}$ (Table 2) transiently decreased $(P<0.05)$ from the cisternal fraction to 50 or $75 \%$ alveolar fractions, then increased towards the end of milking on $\mathrm{d} 2$ and in wk 4 . The concentration of $\mathrm{K}$ and osmolarity (Table 2$)$ increased $(P<0.05)$ from cisternal to alveolar fractions, while electrical conductivity decreased $(P<0.05)$ from cisternal to $100 \%$ alveolar fractions and still in residual fractions. $\mathrm{Cl}$ did not change significantly during milking. Osmolarity (Table 2 ) had its lowest values in the cisternal milk and increased in the alveolar fractions during milking.

Hormones, enzymes, and immunoglobulin $G$ in colostrum. On d 2, concentrations of IGF-I decreased $(P<0.05)$ from cisternal to alveolar fractions. Concentrations of insulin and PRL, and $\gamma$-GT activities transiently decreased on $\mathrm{d} 2(P<0.05)$ in the $25 \%$ alveolar fraction, and increased thereafter (Table 3). Concentrations of IgG did not significantly change during milking.

\section{DISCUSSION}

\section{Milk Components in Composite Milk on d 2 and in wk 4 of Lactation}

Of the various characteristics measured, concentrations of fat, $\mathrm{K}$, and osmolarity did not differ significantly between d 2 and wk 4 of lactation, and thus, behaved slightly different from what is observed during milking on practical dairy farms, likely because residual milk was included.

The DM content was higher in colostrum than in mature milk due to greater amounts of milk solids in colostrum. The high total protein concentration in colostrum was largely due to high amounts of IgG (Guidry et al., 1980b; Butler, 1983; Larson, 1992; Vacher and Blum, 1993). Concentrations of other protein fractions (not measured in this experiment) such as lactoglobulin, lactoferrin, and transferrin are known to be also higher in colostrum than in mature milk (Sanchez et al., 1988; Ye-Xiuyn and Yoshida, 1995). The decreasing total milk protein concentration in mature milk was likely in part due to dilution resulting from increased milk production.

Lactose production causes water influx in milk through osmotic effects, and values were lower in colostrum than in mature milk. However, concentrations of $\mathrm{Na}$ and $\mathrm{Cl}$, which are, osmotically active molecules in milk, were elevated in colostrum compared with mature 
Table 3. Hormones, $\gamma$-GT, and IgG in colostrum (d 2 of lactation).

\begin{tabular}{|c|c|c|c|c|c|c|c|}
\hline \multirow[b]{2}{*}{ Traits } & & \multicolumn{6}{|c|}{ Milk fractions } \\
\hline & & Cisternal & $25 \%$ & $50 \%$ & $75 \%$ & $100 \%$ & Residual \\
\hline IGF-I & $\mu \mathrm{g} / \mathrm{L}$ & $129 \pm 30^{\mathrm{A}}$ & $93.2 \pm 20.3^{\mathrm{C}}$ & $93.6 \pm 16.6^{\mathrm{C}}$ & $106 \pm 23^{\mathrm{B}}$ & $103 \pm 20^{\mathrm{BC}}$ & $97 \pm 19^{\mathrm{BC}}$ \\
\hline PRL & $\mu \mathrm{g} / \mathrm{L}$ & $168 \pm 45^{\mathrm{A}}$ & $113 \pm 15^{\mathrm{C}}$ & $118 \pm 13^{\mathrm{BC}}$ & $138 \pm 24^{\mathrm{AB}}$ & $148 \pm 32^{\mathrm{AB}}$ & $134 \pm 20^{\mathrm{BC}}$ \\
\hline$\gamma$-GT & mkat/L & $157 \pm 17^{\mathrm{A}}$ & $127 \pm 9^{C}$ & $138 \pm 8^{\mathrm{BC}}$ & $152 \pm 11^{\mathrm{AB}}$ & $162 \pm 14^{\mathrm{A}}$ & $109 \pm 12^{\mathrm{C}}$ \\
\hline IgG & $\mathrm{g} / \mathrm{L}$ & $38.3 \pm 8.6$ & $20.6 \pm 3.1$ & $24.3 \pm 3.9$ & $34.5 \pm 7.7$ & $36.2 \pm 11.3$ & $38.3 \pm 10.9$ \\
\hline
\end{tabular}

${ }^{\mathrm{A}, \mathrm{B}}$ Means of milk fractions with different capital letters are significantly different $(P<0.05)$.

milk. Thus, the electrolyte transfer from blood into milk through leaky tight junctions (Nguyen and Neville, 1998) is expected to increase the milk volume during the colostral period despite relatively low lactose secretion.

The SCC were much higher in colostrum than in mature milk. This is in accordance with previous results (Emanuelson and Persson, 1984; Hallberg et al., 1995; Andrew, 2001). Mastitis pathogens are not infrequently found in colostrum (Andrew, 2001). However, in our study there were no indications for a clinical mastitis in the dry or periparturient period. Furthermore, colostrum appearance was always normal (milky, thickened) according to the criteria described by Hallberg et al. (1995). The SCC increases during infection in mature milk as well as in colostrum (Hallberg et al., 1995). However, the SCC in colostrum measured in the multiparous cows $\left(1479 \times 10^{3}\right.$ cells $\left./ \mathrm{mL}\right)$ of our study were markedly below mean values $\left(2458 \times 10^{3}\right.$ cells $\left./ \mathrm{mL}\right)$ found by Andrew (2001), and below the lowest values measured in the fall season $\left(2580 \times 10^{3}\right.$ cells $\left./ \mathrm{mL}\right)$ in the study of Hallberg et al. (1995) in primiparous cows. In addition, the California Mastitis Test was always negative and SCC measured at 7 to $14 \mathrm{~d}$ after parturition (i.e., in mature milk) were always $<100 \times 10^{3}$ cells/ $\mathrm{mL}$ (data not shown). Somatic cell count would still have been elevated at this time if there would have been mastitis during the dry or periparturient period. Therefore, udders on $d 2$ of lactation were considered healthy; i.e., high SCC on d 2 of lactation were of physiological nature and were most likely due to penetration of cells through leaky tight junctions between the mammary epithelial cells (Nguyen and Neville, 1998). In wk 4 (mature milk) the SCC were low because we have tested only cows with healthy udders $\left(<100 \times 10^{3}\right.$ cells/mL).

The IGF-I concentration dropped drastically from colostrum to mature milk in accordance with Ronge and Blum (1988), Vega et al. (1991), and Campana and Baumrucker (1995). The high amounts of PRL and insulin on $\mathrm{d} 2$ of lactation were probably the consequence of a marked influx from blood into milk through leaky tight junctions (Nguyen and Neville, 1998) or by transcellular routes (Ollivier-Bousquet, 1993). In addition, the TNF- $\alpha$ concentration was higher in colostrum than in mature milk. TNF- $\alpha$ also has chemotactic activity and is involved in the influx of somatic cells from blood into milk. Gene expression of TNF- $\alpha$ by milk somatic cells was increased in quarters with increased immunological activity (Wittmann et al., 2002). Thus, TNF- $\alpha$ may be produced by somatic cells, in part, to regulate further influx of cells into milk.

The $\gamma$-GT is known to be localized on the outer surface of the alveolar cell membrane to promote absorption of some amino acids across alveolar cell membranes (Baumrucker and Pocius, 1978). The activity of $\gamma$-GT was much higher on $\mathrm{d} 2$ than in wk 4, which agrees with previous findings (Hadorn et al., 1997).

The IgG concentration was higher on $d 2$ than in wk 4, demonstrating enhanced passage from blood into milk through leaky tight junctions and epithelial secretory cells (Butler, 1983; Ollivier-Bousquet, 1993). After the colostral period, the IgG is transported from blood into milk only by transcellular selective receptor-mediated transcytosis (Hammer and Mossman, 1976; Guidry et al., 1980; Butler, 1983), thus explaining reduced concentrations in wk 4.

Concentrations of $\mathrm{Na}$ and $\mathrm{Cl}$ were closely correlated with those of IgG on $\mathrm{d} 2$. This implies that $\mathrm{Na}$ and $\mathrm{Cl}$ may pass into milk simultaneously with IgG, although transport mechanisms are expectedly much different from IgG. Their appearance in milk at these stages is primarily regulated by a passage through epithelial cells (Peaker and Linzell, 1975).

Electrical conductivity was higher in colostrum than in mature milk because it is related to greater amounts of $\mathrm{Na}, \mathrm{Cl}$, and $\mathrm{K}$ in colostrum and in mature milk (Wheelock et al., 1966).

\section{Changes in Milk Composition During the Course of Milking}

Amounts of DM increased during milking both on d 2 and in wk 4 of lactation. This was due to increased concentration of some milk components. Thus, fat concentration increased continuously from the cisternal to the alveolar (100\%) fraction and increased further in 
the residual fraction during milking. Milk fat has a lower specific gravity than water and before milk removal, fat may ascend within the alveolar lumina, thus causing an increasing fat content during removal of the alveolar fraction. In addition, fat droplets during milking may move less rapidly than the aqueous phase, and are influenced by capillary and adhesive forces. Therefore, fractions with the highest fat concentration are removed at the end of milking. Thus, incomplete milk ejection and removal causes a considerable reduction in milk fat. Calves, if consuming only a portion of the stored milk, may ingest only small amounts of fat.

Milk protein concentration in colostrum was higher in the cisternal fraction than in subsequent fractions and reached lowest values in the residual fraction. The high concentration in cisternal colostrum may in part be due to high IgG levels in this fraction, which represents a considerable percentage of the total protein. In mature milk, the protein content did not change significantly until the $75 \%$ fraction, but also decreased at the end of milking, with lowest values in the residual fraction. In mature milk, this phenomenon was shown previously (Wittkowski et al., 1979); the reasons, however, are unclear.

The pattern of SCC during the course of milking, i.e., high values in cisternal milk, low values in the first alveolar fraction and a steady rise until the end of milking was in accordance with previous investigations (Wittkowski et al., 1979). Usually, quarter cisternal milk samples are analyzed for udder health monitoring. Milk ejection can occur within $40 \mathrm{~s}$ after the start of a tactile teat contact (Bruckmaier and Hilger, 2001). Thus, quarter milk sampling must be performed within $40 \mathrm{~s}$ to avoid a decline of SCC due to a dilution caused by alveolar milk ejection. Concentrations of PRL, insulin, and $\gamma$-GT activities (measured only on d 2 of lactation because concentrations or activities were too low in wk 4) changed significantly during milking with high values in the cisternal milk, lowest values in the $25 \%$ fraction. This finding suggests similar mechanisms of distribution in the mammary gland compartments and milk fractions. Thus, IgG, $\gamma$-GT, and IGF-I are transported into the alveolar space by para- and/or transcellular mechanisms, and PRL is secreted primarily transcellularly into milk, similar to casein (Ollivier-Bousquet, 1993).

Concentrations of $\mathrm{Na}$ and $\mathrm{K}$ varied significantly during milking and among animals, while the concentration of $\mathrm{Cl}$ did not differ during milking, suggesting that these substances are transported differently into and distributed among udder compartments. Although the concentrations of $\mathrm{Na}$ and $\mathrm{Cl}$ as osmotically active substances were relatively high in the cisternal fraction, osmolarity was always low at the start of milking and increased thereafter on $\mathrm{d} 2$ and in wk 4 , indicating that increasing lactose concentration in the alveolar milk exerts the main osmotic activity.

Electrical conductivity was highest in the cisternal fraction at both periods of lactation, and associated with relatively high concentrations of $\mathrm{Na}$ and $\mathrm{Cl}$. Despite an overall trend of increasing electrolyte concentrations toward the end of milking, of electrical conductivity decreased. This was most likely due to the simultaneous increase in milk fat content, which has been identified as a factor decreasing electrical conductivity (Fernando et al. 1981; Hamann et al., 1995). Measurement of electrical conductivity to show changes electrolyte concentrations due to mastitis-related damage of tight junctions (Nguyen and Neville, 1998) may show highest sensitivity in the cisternal fraction where electrolyte concentrations are high and milk fat concentration is low.

In conclusion, changes in concentrations of milk components in different milk fractions illustrate that some constituents such as fat are not equally distributed within udder compartments after their secretion. These changes have to be considered if milk samples are taken for analysis of their constituents. Increased osmolarity, despite a significant decrease in lactose concentration toward the end of milking, illustrates that electrolytes are involved in the regulation of milk isotonicity.

\section{ACKNOWLEDGMENTS}

This study was supported in part by the Swiss Federation for Artificial Insemination, Zollikofen, Switzerland and by Central Federation of Swiss Milk Producers, Berne, Switzerland. We thank the Swiss Simmental Association, Zollikofen, for performing milk analyses. The technical assistance of C. Morel and Y. Zbinden, Div. of Animal Nutrition and Physiology, Faculty of Veterinary Medicine, Univ. of Berne, is greatly appreciated.

\section{REFERENCES}

Andrew, S.M. 2001. Effect of composition of colostrum and transition milk from Holstein heifers on specificity rates of antibiotic residue tests. J. Dairy Sci. 84:100-106.

Baumrucker, C. R., and P. A. Pocius. 1978. $\gamma$-Glutamyltranspeptidase in lactating mammary secretory tissue of cow and rat. J. Dairy Sci. 61:309-314.

Blum, J. W., and H. M. Hammon. 2000. Colostrum effects on the gastrointestinal tract, and on nutritional, endocrine and metabolic parameters in neonatal calves. Livest. Prod. Sci. 66:151159.

Blum J. W., and C. R. Baumrucker. 2002. Colostral insulin-like growth factors and related substances: mammary gland, and neonatal (intestinal and systemic) targets. Domest. Anim. Endocrinol. 23:101-110. 
Blum, J. W., H. Dosogne, D. Hoeben, F. Vangroenweghe, H. M. Hammon, R. M. Bruckmaier, and C. Burvenich. 2000. Tumor necrosis factor- $\alpha$ and nitrite/nitrate responses during acute mastitis induced by Escherichia coli infection and endotoxin in dairy cows. Domest. Anim. Endocrinol. 19:223-235.

Bruckmaier, R. M., and J. W. Blum. 1996. Simultaneous recording of oxytocin release, milk ejection and milk flow during milking or dairy cows with and without prestimulation. J. Dairy Res. 63:201-208.

Bruckmaier, R. M., and J. W. Blum. 1998. Oxytocin release and milk removal in ruminants. J. Dairy Sci. 81:939-949.

Bruckmaier, R. M., and M. Hilger. 2001. Milk ejection in dairy cows at different degrees of udder filling. J. Dairy Res. 68:369-376.

Bruckmaier, R. M., E. Rothenanger, and J. W. Blum. 1994a. Measurement of mammary gland cistern size and determination of cisternal milk fraction in dairy cows. Milchwiss. 49:543-546.

Bruckmaier, R. M., D. Schams, and J. W. Blum. 1994b. Continuously elevated concentrations of oxytocin during milking are necessary for complete milk removal in dairy cows. J. Dairy Res. 61:323-334.

Butler, J. E. 1983. Bovine immunoglobulins: an augmented review. Vet. Immunol. Immunopathol. 4:43-152.

Campana, W. M., and C. R. Baumrucker. 1995. Growth factors in bovine milk. Pages 474-494 in Handbook of Milk Composition. R. G. Jensen, ed. Academic Press, San Diego, CA.

Davis, S. R., V. C. Farr, P. J. A. Copeman, V. R. Carruthers, C. H. Knight, and K. Stelwagen. 1998. Partitioning of milk accumulation between cisternal and alveolar compartments of the bovine udder: relationship to production loss during once daily milking. J. Dairy Res. 65:1-8.

Emanuelson, U. L. F., and E. Persson. 1984. Studies on somatic cell counts in milk from Swedish dairy cows: nongenetic causes of variation in monthly test-day results. Acta Agriculturae Scandinavica 34:33-44.

Fernando, R. S., R. B. Rindsig, and S. L. Spahr. 1981. Effect of length of milking interval and fat content on milk conductivity and its use for detecting mastitis. J. Dairy Sci. 64:678-682.

Guidry, A. J., J. E. Butler, R. E. Pearson, and B. T. Weinland. 1980. IgA, $\operatorname{IgG}_{1}, I g G_{2}, I g M$, and BSA in serum and mammary secretion throughout lactation. Vet. Immunol. Immunopathol. 1:329-341.

Hadorn, U., H. Hammon, R. M. Bruckmaier, and J. W. Blum. 1997. Delaying colostrum intake by one day has important effects on metabolic traits and gastrointestinal and metabolic hormones in neonatal calves. J. Nutr. 127:2011-2023.

Hallberg, J. W., K. J. Dame, S. T. Chester, C. C. Miller, L. K. Fox, J. W. Pankey, S. C. Nickerson, and L. J. Weaver. 1995. The visual appearance and somatic cell count of mammary secretions collected from primigravid heifers during gestation and early postpartum. J. Dairy Sci. 78:1629-1636.

Hamann, J., B. Nipp, and P. Gyodi. 1995. Comparison of hand-held instruments for measuring the electrical conductivity of milk. Milchwiss. 50:543-546.

Hammer, D. K., and H. Mossman. 1976. The importance of membrane receptors in the transfer of immunoglobulins from plasma to the colostrum. Ann. Rech. Vet. 9:229-234.

Jans, F., and J. Kessler. 1999. Fütterungsempfehlungen für die Milchkuh. Pages 83-112 in Fütterungsempfehlungen und Nährwerttabellen für Wiederkäuer. Eidgenössische Forschungsans- talt für Nutztiere, Posieux, Switzerland. 4th ed. Landwirtschaftliche Lehrmittelzentrale, Zollikofen, Switzerland.

Knight, C. H., Hirst, D., and R. J. Dewhurst. 1994. Milk accumulation and distribution in the bovine udder during the interval between milkings. J. Dairy Res. 61:167-177.

Koldovsky, O. 1980. Hormones in milk. J. Dairy Sci. 26:1833-1836.

Larson, B. L. 1992. Immunoglobulins of the mammary secretions. Pages 215-240 in Advanced Dairy Chemistry-1: Proteins. P. F. Fox, ed., Elsevier, London, New York.

Lee, C.-S., F. B. P. Wooding, and P. Kemp. 1980. Identification, properties, and differential counts of cell populations using electron microscopy of dry cows secretions, colostrum and milk from normal cows. J. Dairy Res. 47:39-50.

Nguyen, D. D., and M. C. Neville. 1998. Tight junction regulation in the mammary gland. J. Mammary Gland Biol. Neopl. 3:233-246.

Peaker, M., and J. L. Linzell. 1975. Citrate in milk: a harbinger of lactogenesis. Nature 253:1975.

Ollivier-Bousquet, M. 1993. Les hormones du lait: provenances et rôles. INRA Prod. Anim. 6:253-263.

Patton, S., and R. G. Jensen. 1975. Lipid metabolism and membrane functions of the mammary gland. Pages 193-210 in Progress in the Chemistry of Fats and Other Lipids. Vol. 14. R. T. Holman, ed. Pergamon Press, Oxford, Great Britain.

Ronge, H., and J. W. Blum. 1988. Somatomedin C and other hormones in dairy cows around parturition, in newborn calves and in milk. J. Anim. Physiol. a. Anim. Nutr. 60:168-174.

Sanchez, L., P. Aranda, M. D. Pérez, and M. Calvo. 1988. Concentrations of lactoferrin and transferrin throughout lactation in cow's colostrum and milk. Biol. Chem. 369:1005-1008.

Swaisgood, H. E. 1995. Enzymes indigenous to bovine milk. Pages 472-476 in Handbook of Milk Composition, R. G. Jenscer, ed. Academic Press, New York.

Vacher, P.-Y., and J. W. Blum. 1993. Age-dependency of insulinlike growth factor-I, insulin, protein and immunoglobulin concentrations and $\gamma$-glutamyltransferase activity in first colostrum of dairy cows. Milchwiss. 48:423-428.

Vega, J. R., C. A. Gibson, T. C. Skaar, D. L. Hadsell, and C. R. Baumrucker. 1991. Insulin-like growth factor (IGF)-I and -II and IGF binding proteins in serum and mammary secretions during the dry period and early lactation in dairy cows. J. Anim. Sci. 69:2538-2547.

Wellnitz, O., R. M. Bruckmaier, and J. W. Blum. 1999. Milk ejection and removal of single quarters in high yielding dairy cows. Milchwiss. 54:303-306.

Wheelock, J. V., J. A. F. Rook, F. K. Neave, and F. H. Dodd. 1966. The effect of bacterial infection of the udder on the yield and composition of cow's milk. J. Dairy Res. 33:199-215.

Wilde, C., and M. Peaker. 1990. Autocrine control in milk secretion. J. Agric. Sci. 114:235-238.

Wittkowski, G., W. Gedek, and E. Kleinschroth. 1979. Mastitisdiagnostisch wichtige Meßwerte von fraktioniert gewonnenen Milchproben beim Rind. Arch Lebensmittelhyg. 30:19-22.

Wittmann, S. L., M. Pfaffl, H. H. D. Meyer, and R. M. Bruckmaier. 2002. 5-Lipoxygenase, cyclooxygenase-2 and tumor necrosis factor alpha gene expression in somatic milk cells. Milchwiss. 57:63-66.

Ye-Xiuyn, X. Y., and S. Yoshida. 1995. Lactoperoxidase and lactoferrin: Changes in post partum milk during bovine lactational disorders. Milchwiss. 50:67-70. 